\author{
Dr hab. Barbara DANOWSKA-PROKOP, prof. UE \\ Katedra Ekonomii, Uniwersytet Ekonomiczny w Katowicach \\ e-mail: barbara.danowska-prokop@ue.katowice.pl \\ ORCID: 0000-0002-5030-9220
}

DOI: $10.15290 /$ oes.2019.02.96.06

\title{
UBEZPIECZENIA BRACKIE I ICH FUNKCJONOWANIE NA GÓRNYM ŚLĄSKU W OKRESIE MIĘDZYWOJENNYM ${ }^{1}$
}

\begin{abstract}
Streszczenie
Cel - W górnośląskiej części województwa śląskiego w latach 1922-1939 działała Spółka Bracka w Tarnowskich Górach i Pszczyńskie Bractwo Górnicze. Obie instytucje brackie oferowały świadczenia chorobowe oraz emerytalno-rentowe, przy czym poziom otrzymywanych świadczeń i płaconych składek zależał od stanu koniunktury. Celem artykułu jest ukazanie zależności między sytuacją gospodarczo-społeczną a warunkami funkcjonowania zawodowego ubezpieczenia brackiego na Górnym Śląsku w latach 1922-1939.

Metoda badań - Skorzystano z metody analizy materiałów źródłowych i przeglądu literatury przedmiotu, metody opisu.

Wyniki - Unikatowość Górnego Śląska pod względem polityczno-ustrojowym i społeczno-gospodarczym zaważyła na wyjątkowości systemu zabezpieczeń społecznych. Dobrowolne zawodowe ubezpieczenia brackie żywo reagowały na zmiany w stanie koniunktury.

Oryginalność/wartość - Poruszany w pracy problem dostarcza wiedzy o mechanizmach funkcjonowania dobrowolnych instytucji ubezpieczeniowych, zwłaszcza emerytalnych.
\end{abstract}

Słowa klucze: ubezpieczenia brackie, zabezpieczenia społeczne, koniunktura

\section{BRACKIE INSURANCE AND ITS FUNCTIONING IN UPPER SILESIA IN THE INTERWAR PERIOD}

\section{Summary}

Purpose - The Bracka company operated in Tarnowskie Góry and The Brotherhood of Miners in Pszczyna in Upper Silesian parts of Silesian Voivodeship in the years 1922-1939. Both institutions offered sickness and retirement benefits, as well as the disability ones. The level of benefits received and contributions paid depended on the economic situation. The purpose of the article is to show the relationship between the economic and social situation and the conditions of the professional Brackie insurance in Upper Silesia in the years 1922-1939.

Research method - While writing the paper, the method of the source material analysis and literature review were used, as well as descriptive method.

1 Artykuł wpłynął 23 października 2018 r., zaakceptowano 13 grudnia 2018 r.

Article received 23 October 2018, accepted 13 December 2018. 
Results - The uniqueness of Upper Silesia in terms of the political and the socio-economic system influenced the uniqueness of the social security system. The voluntary professional Brackie insurance responded to changes in the economic situation.

Originality/value - The problem raised in the paper provides knowledge about the mechanisms of functioning of voluntary insurance institutions, especially those connected to the retirement system.

Key words: brackie insurance, social security, business prosperity

JEL classification: B22, E32, H53

\section{Wstęp}

W okresie międzywojennym w górnośląskiej części województwa śląskiego występował dualizm ubezpieczeniowy. Obok ogólnokrajowego, obligatoryjnego systemu ubezpieczeń, funkcjonowały dobrowolne, zawodowe (branżowe) ubezpieczenia górnicze tzw. ubezpieczenia brackie. Do bractw przynależały wszystkie kopalnie węgla i kruszców, a także przedsiębiorstwa przetwórcze powiązane z branżą górnicza.

Ubezpieczenia brackie gwarantowały swym członkom i ich rodzinom, nie tylko dodatkową opiekę medyczna, ale i dodatkowe świadczenia emerytalno-rentowe, które pozytywnie oddziaływały na poziom życia miejscowej ludności.

\section{Ubezpieczenia brackie w górnośląskiej części województwa śląskiego w latach 1922-1939}

U progu niepodległości funkcjonowały obok siebie cztery różne systemy ustawodawstwa w zakresie ubezpieczeń społecznych: rosyjski - opierał się tylko na zasadzie zaopatrzenia, austriacki i niemiecki - opierały się na zasadzie zabezpieczenia oraz system branżowy - funkcjonujący w przemyśle wydobywczym (głównie na Górnym Śląsku). Uwzględniając powyższą niespójność systemową Ministerstwo Pracy i Opieki Społecznej, już w pierwszych miesiącach 1919 r., rozpoczęło prace nad budowa własnego, spójnego oraz scentralizowanego systemu ubezpieczeniowego (prace zakończyły się w 1933 r.). Już w pierwszej połowie lat 20. XX w., powstały zręby nowego systemu, w ramach którego funkcjonowały cztery rodzaje ubezpieczeń społecznych: emerytalne, wypadkowe, chorobowe (zorganizowane na wzór niemiecki - kasy chorych) i od bezrobocia.

Wprowadzane rozwiazzania obowiązywały na całym terytorium II Rzeczypospolitej, łącznie z autonomicznym województwem ślaskim. Przy czym w województwie śląskim funkcjonowały równolegle zawodowe ubezpieczenia górnicze [Kozłowski, 1923; Jastrzębowski, 1923; Gruber, 1928].

Odmienność ubezpieczeniowa górnośląskiej części województwa śląskiego wynikała ze względów polityczno-społecznych, jak i gospodarczych, własnościowych, zawodowych oraz narodowościowo-wyznaniowych. Odrębność ubezpieczeniowa 
znalazła potwierdzenie w zapisach statutu organicznego (kwestie ubezpieczeń społecznych przynależały do wyłącznej kompetencji Sejmu Śląskiego) oraz w postanowieniach polsko-niemieckiej konwencji górnośląskiej. Dzięki powyższym uregulowaniom górnicy korzystali z dobrodziejstwa państwowego systemu ubezpieczeń społecznych oraz zawodowego ubezpieczenia górniczego [Biały, 1967, s. 105-110; Danowska-Prokop, 2012, s. 131-142; Drozdowski, 1938, s. 209-210; Falęcki, 1937, s. 683-697; Jońca, 1966, s. 190-191; Popiołek, 1946, s. 27-28; Szczęśniak, 2003, s. 49-55; Wanatowicz, 1973, s. 33-39].

Funkcjonujące $\mathrm{w}$ górnośląskim górnictwie ubezpieczenia brackie oferowały dodatkowe świadczenia, do których uprawnieni byli robotnicy i nisko uposażeni urzędnicy zatrudnieni w przemyśle węglowym oraz w administracji brackiej. W ten sposób członkowie bractw dysponowali prawem nie tylko do podwójnego świadczenia emerytalno-rentowego (pensyjnego), ale także do dodatkowych świadczeń medycznych, oferowanych przez brackie kasy chorych.

W okresie międzywojennym brackie ubezpieczenia górnicze ograniczyły swą działalność do dwóch obszarów [Mamrotowa, 1933]:

- zdrowotnej, w ramach której oferowano pomoc medyczną i pieniężna,

- emerytalno-rentowej (pensyjnej), w ramach której oferowano świadczenia inwalidzko-emerytalne, wdowie (tzw. grosz wdowi) oraz sieroce (tzw. grosz sierocy).

W okresie walki o przynależność Górnego Śląska strona polska zdecydowała się przyznać powstającemu województwu ślaskiemu unikatowe rozwiązania prawne, ograniczające suwerenność państwa polskiego. Sejm Ustawodawczy RP w dniu 15 lipca 1920 r. uchwalił konstytucję zawierającą Statut Organiczny Województwa Śląskiego, który wprowadzał autonomię. Statut - „konstytucja śląska” - regulował wszystkie kwestie związane z funkcjonowaniem tego województwa, a w szczególności relacje między samorządowym województwem a administracją centralną oraz precyzował uprawnienia samorządu śląskiego [Ustawa..., 1920; Ciagwa, 1979, s. 27-42; Ciągwa, 2005, s. 45-48; Marcoń, 2009, s.16-69].

\section{1. Świadczenia brackiej kasy chorych}

W sferze zdrowotnej funkcjonowały brackie kasy chorych, ubezpieczające zarówno górników, jak i członków ich rodzin. Jakość oferowanych świadczeń medycznych zależała bezpośrednio od bieżącego stanu koniunktury (od wysokości uiszczanych składek, przy czym $1 / 2$ składki uiszczał pracodawca a $1 / 2$ ubezpieczony): w latach osłabienia koniunktury malała liczba pracujących członków i odpowiednio zmniejszały się wpływy. Zatem stan koniunktury decydował nie tylko o poziomie, ale i o jakości rzeczowych świadczeń medycznych, w tym o standardzie opieki lekarskiej i stomatologicznej w otwartych lub zamkniętych placówkach medycznych oraz o wysokości wypłacanych świadczeń pieniężnych w postaci: zasiłku chorobowego, zasiłku połogowego, zasiłku pośmiertnego i pogrzebowego oraz zapomóg dla osób żyjących w niedostatku. Powyższa prawidłowość znajduje potwierdzenie w danych zaprezentowanych w tabelach 1, 2 i 3 . 
TABELA 1

Członkowie kasy chorych Spółki Brackiej w Tarnowskich Górach w latach 1922-1938 (według stanu na koniec roku)

\begin{tabular}{|l|c|c|c|}
\hline Rok & Członkowie & Rok & Członkowie \\
\hline 1922 & 167688 & 1931 & 84003 \\
\hline 1923 & 169171 & 1932 & 63791 \\
\hline 1924 & 113267 & 1933 & 59539 \\
\hline 1925 & 88308 & 1934 & 59813 \\
\hline 1926 & 99365 & 1935 & 58935 \\
\hline 1927 & 90399 & 1936 & 59935 \\
\hline 1928 & 97155 & 1937 & 65393 \\
\hline 1929 & 109149 & 1938 & 67236 \\
\hline 1930 & 94504 & & \\
\hline
\end{tabular}

Źródło: [Sprawozdania Spótki Brackiej..., 1922-1938].

Z danych zaprezentowanych w tabeli 1 wynika jednoznacznie, że wahania w koniunkturze (w wydobyciu i sprzedaży węgla oraz w zatrudnieniu) wiązały się ze zmianami w liczebności i w dochodach brackiej kasy chorych, a także w poziomie i jakości oferowanych świadczeń medycznych (procedur medycznych). Szczególnie niekorzystne tendencje wystapiły na przestrzeni lat 1924-1925 i 1930-1934. W pierwszym przypadku spadek liczebności brackich kas był następstwem jednoczesnego zadziałania dwóch czynników: spadku popytu na węgiel na rynku krajowym oraz wojny celnej z Niemcami (po odmowie przyjęcia węgla przez stronę niemiecką górnośląscy producenci zmuszeni byli poszukiwać nowych rynków zbytu). Natomiast w drugim przypadku spadek był następstwem wielkiego kryzysu ekonomicznego: malejącemu zatrudnieniu towarzyszył spadek płac oraz wpływów do brackich kas (zgodnie ze statutami osoby zatrudnione w niepełnym wymiarze czasu pracy uiszczały tylko symboliczne opłaty uznaniowe, a bezrobotni członkowie byli zwolnieni z obowiązku uiszczania składek). Zatem odpływowi „właściwych” członków kas chorych towarzyszył „przypływ” pensjonistów (emerytów) oraz członków ich rodzin, którzy dysponowali prawem do świadczeń medycznych.

Wśród członków brackich kas chorych podstawową grupę stanowili obowiązkowo ubezpieczeni, natomiast dobrowolnie ubezpieczeni: urzędnicy oraz pracownicy przedsiębiorstw przetwórczych, stanowili znikomy procent. 
TABELA 2

Wydatki na świadczenia rzeczowe i pieniężne kasy chorych Spółki Brackiej w Tarnowskich Górach w wybranych latach: 1925, 1929, 1935, 1938*

\begin{tabular}{|l|c|c|c|}
\hline Rok & $\begin{array}{c}\text { Wydatki } \\
\text { ogółem [zł] }\end{array}$ & $\begin{array}{c}\text { Świadczenia rze- } \\
\text { czowe [\%] }\end{array}$ & $\begin{array}{c}\text { Świadczenia } \\
\text { gotówkowe [\%] }\end{array}$ \\
\hline 1925 & 9733211 & 78,8 & 21,2 \\
\hline 1929 & 18099700 & 65,9 & 34,1 \\
\hline 1935 & 10884651 & 83,1 & 16,9 \\
\hline 1938 & 12454286 & 83,0 & 17,0 \\
\hline
\end{tabular}

* w uwzględnionych latach występowały albo pozytywne albo negatywne następstwa spadku aktywności gospodarki.

Źródło: [Sprawozdania Spółki Brackiej..., 1925-1938].

Dane zaprezentowane w tabeli 2 potwierdzają już wcześniej sformułowane wnioski, że: stan koniunktury decydował o dochodach i wydatkach brackich kas chorych oraz determinował proporcje podziału środków na świadczenia rzeczowe i pieniężne (świadczenia pieniężne przysługiwały tylko członkom pracującym, przy czym w okresie pogorszenia koniunktury środki przeznaczane na ten cel były ograniczane).

TABELA 3

Dochody i wydatki (w zł) kasy chorych Spółki Brackiej w Tarnowskich Górach w latach 1922-1938

\begin{tabular}{|l|c|c|c|}
\hline Rok & Dochody & Wydatki & $\begin{array}{c}\text { Procent pokrycia } \\
\text { wydatków }\end{array}$ \\
\hline 1924 & 18474009 & 11432400 & 161,6 \\
\hline 1925 & 9370467 & 10536323 & 88,9 \\
\hline 1926 & 9990589 & 11265323 & 88,6 \\
\hline 1927 & 13389951 & 12903814 & 103,7 \\
\hline 1928 & 16709486 & 15613808 & 107,0 \\
\hline 1929 & 20840648 & 19504873 & 106,8 \\
\hline 1930 & 20699453 & 19919369 & 103,9 \\
\hline 1931 & 28431364 & 18353832 & 154,9 \\
\hline 1932 & 14693542 & 14458669 & 101,6 \\
\hline 1933 & 11527202 & 13172492 & 87,5 \\
\hline 1934 & 11868714 & 11868714 & 100,0 \\
\hline 1935 & 11709538 & 11731986 & 100,4 \\
\hline 1936 & 11787876 & 11731060 & 110,2 \\
\hline 1937 & 13186056 & 11964579 & 109,6 \\
\hline 1938 & 14712685 & 13416678 & \\
\hline
\end{tabular}

Źródło: [Sprawożdania Spótki Brackiej..., 1922-1938]. 
Z zaprezentowanych danych wynika, że w latach 1924-1938 roczny budżet kasy chorych aż jedenastokrotnie wykazywał nadwyżkę, a jedynie czterokrotnie niedobór (niedobory pokrywano ze zakumulowanych środków, a także z dodatkowych źródeł dochodu, czyli: wynajmu ruchomości i nieruchomości, z lokat bankowych i kapitałowych, bowiem bractwa działały na zasadzie kapitałowego pokrycia zobowiązań). Wyjątkowo niekorzystny stosunek dochodów do wydatków przypadał na lata 19251926 oraz na rok 1933, w którym to wystąpił największy niedobór w kasie chorych przekroczył kwotę 1645290 zł, tj. 12,5\% ogółu wydatków. Od 1935 r. sytuacja finansowa kasy wykazywała oznaki poprawy (efekt ożywienia koniunktury, wzrostu zatrudnienia i płac w górnictwie), co przyczyniło się do odtworzenia nadwyrężonych oszczędności.

Podobne prawidłowości obserwuje się w działalności pszczyńskiej kasy chorych. Przejściowe zakłócenia w działalności pojawiły się w latach 1925-1926 oraz w latach 1932-1933. Pojawiające się w tym okresie niedobory pokrywano z nadwyżek powstałych w lepszych okresach [Wanatowicz, 1971].

Obie brackie kasy chorych udzielały świadczeń dużej grupie pracujących (w chwili podziału Górnego Śląska do kas chorych obu spółek brackich należało ponad 200 tys. robotników) i dlatego pozytywnie oddziaływały na życie społecznogospodarcze regionu. W latach 20. XX w. ze Spółką Bracką w Tarnowskich Górach oraz z Pszczyńskim Bractwem Górniczym związanych było stosunkiem ubezpieczeniowym ponad 500 tys. mieszkańców (na około $1 \mathrm{mln}$ ogółu mieszkańców). W latach wielkiego kryzysu gospodarczego liczba ubezpieczonych zmniejszyła się o $1 / 3$, ale ponad 330 tys. mieszkańców w dalszym ciagu korzystało z dobrodziejstwa ubezpieczenia brackiego. Ubezpieczeni osiagali dwojakie korzyści: po pierwsze dobrą opiekę lekarska (dostosowaną do potrzeb zawodowych górników) i łatwy dostęp do środków medycznych, po drugie - wsparcie finansowe w przypadku wystapienia nieprzewidywalnego zdarzenia losowego.

\subsection{Brackie kasy pensyjne}

W sferze emerytalno-rentowej (pensyjnej) ubezpieczeni członkowie przynależeli do kasy pensyjnej Spółki Brackiej w Tarnowskich Górach lub kasy pensyjnej Pszczyńskiego Bractwa Górniczego (w 1923 r. do kas pensyjnych należało ponad 150 tys. osób), które gwarantowały środki na starość (podstawą finansowania emerytur były składki płacone przez ubezpieczonych i pracodawców w stosunku pół na pół) oraz świadczenia inwalidzko-rentowe. Obowiązkiem ubezpieczenia w brackich kasach pensyjnych objęci byli jedynie robotnicy zakładów brackich, którzy jednocześnie przynależeli do brackich kas chorych. Ponadto członkowie kas pensyjnych dzielili się na 2 grupy:

- członków czynnych, czyli pracujących, płacących składki pensyjne oraz niepobierających świadczeń rentowych (brackie przepisy ubezpieczeniowe przewidywały, że warunkiem przyjęcia do kasy pensyjnej było ukończenie 16 roku życia i nieprzekroczenie 40 roku oraz dobry stan zdrowia potwier- 
dzony orzeczeniem brackiego lekarza, a członkostwo rozpoczynało się z chwila podjęcia pracy i kończyło z chwila zakończenia pracy),

- członków biernych, czyli niepracujących i niepłacących, ale pobierających świadczenia pensyjne, tzw. pensjonistów (w zależności od charakteru stosunku ubezpieczeniowego dzielili się na 3 podstawowe grupy: inwalidów wojennych oraz zwyczajnych, wdowy i sieroty).

Czynni członkowie zobligowani byli do systematycznego i regularnego uiszczania składek. Natomiast wysokość otrzymywanej pensji brackiej uzależniona była od dwu czynników: wysokości uiszczanych składek i długości okresu składkowego.

TABELA 4

Członkowie kasy pensyjnej Spółki Brackiej w Tarnowskich Górach w latach 1922-1938 (według stanu na koniec roku)

\begin{tabular}{|l|c|c|c|c|c|}
\hline \multicolumn{1}{|c|}{ Rok } & Ubezpieczeni & Pracujący & Rok & Ubezpieczeni & Pracujący \\
\hline 1922 & 144090 & 134900 & 1931 & 89877 & 75781 \\
\hline 1923 & 145520 & 97707 & 1932 & 82926 & 57405 \\
\hline 1924 & 132390 & 76806 & 1933 & 82632 & 51459 \\
\hline 1925 & 100934 & 86464 & 1934 & 158594 & 51630 \\
\hline 1926 & 96183 & 141653 & 1935 & 155901 & 50262 \\
\hline 1927 & 93654 & 79271 & 1936 & 154710 & 51459 \\
\hline 1928 & 89801 & 83657 & 1937 & 154610 & 58485 \\
\hline 1929 & 95847 & 93453 & 1938 & 104355 & 59879 \\
\hline 1930 & 96068 & 81874 & & & \\
\hline
\end{tabular}

Źródło: [Sprawozdania Spótki Brackiej..., 1922-1938].

Świadczenia emerytalno-rentowe gwarantowały dodatkowe dochody po osiągnięciu wieku emerytalnego (ich wysokość uzależniona była od stanu koniunktury) lub po wystapieniu niekorzystnego zdarzenia losowego (trwałej niezdolności do pracy). Dane o liczbie członków kasy pensyjnej w Spółce Brackiej w Tarnowskich Górach przedstawia tabela 4 . W tym przypadku zmiany w koniunkturze odbijały się w liczebności kasy pensyjnej. W latach dobrej koniunktury liczba członków rosła, a wraz z jej pogorszeniem - malała. Tendencja spadkowa przybrała na sile w latach wielkiego kryzysu gospodarczego. Od 1930 r. doszło do zakłócenia relacji między ubezpieczonymi a pracującymi. Z każdym kolejnym rokiem kryzysu szybko rosła liczba ubezpieczonych oraz malała pracujących uiszczających składki (powyższą tendencję potwierdzają dane zaprezentowane w następnej tabeli). Gwałtowny wzrost liczby ubezpieczonych był następstwem [Danowska-Prokop, 2012, s. 147-152; Wanatowicz, 1995]:

- polsko-niemieckiej umowy o ubezpieczeniu społecznym z 11 czerwca 1931 r., dzięki której ponad 25 tys. osób odzyskało prawo do świadczeń lub trwania stosunku ubezpieczeniowego, 
- $\quad$ przywrócenia przepisu o zwolnieniu bezrobotnych z opłaty uznaniówek za okres bezrobocia, stąd wszyscy bezrobotni z przedsiębiorstw brackich (prawie 75 tys. osób) uznani zostali za ubezpieczonych.

Świadczenie rentowe (bracka pensja inwalidzka) przysługiwało wówczas, gdy bracka komisja lekarska potwierdziła trwałą niezdolność do pracy zarobkowej. Jednak, gdy ubezpieczony w kasie pensyjnej dysponował prawem do renty z powszechnego ubezpieczenia emerytalnego był pozbawiany prawa do świadczenia brackiego (chyba, że przekroczył sześćdziesiąty rok życia). W przypadku śmierci uprawnionego prawo do renty przechodziło automatycznie na wdowę (renta wdowia przyznawana była niezależnie od stanu zdrowia, wieku lub sytuacji materialnej). Wdowa otrzymywała połowę świadczenia rencisty. Prawo to wygasło w przypadku ponownego zawarcia związku małżeńskiego (w ramach rekompensaty otrzymywała jednorazowe odszkodowanie w wysokości rocznej pensji wdowiej). Dzieciom (do 15 roku życia) po zmarłym renciście przysługiwało prawo do zapomogi sierocej (w przypadku braku obu rodziców) lub półsierocej (w przypadku braku jednego rodzica), wypłacanej w stałych ratach. Świadczenia dla półsieroty wynosiły $3 / 5$ świadczenia przyznawanego pełnej sierocie [Wieniawa-Chmielewski, 1934].

TABELA 5

\section{Przeciętne miesięczne pensje inwalidów, wdów i sierot Spółki Brackiej w Tarnowskich Górach w latach 1924-1938 (w zł)}

\begin{tabular}{|l|c|c|c|}
\hline Rok & $\begin{array}{c}\text { Przeciętne pensje } \\
\text { inwalidzkie }\end{array}$ & $\begin{array}{c}\text { Przeciętne pensje } \\
\text { wdowie }\end{array}$ & $\begin{array}{c}\text { Przeciętne pensje } \\
\text { sieroce }\end{array}$ \\
\hline 1924 & 35,25 & 17,15 & 6,00 \\
\hline 1925 & 44,16 & 19,20 & 6,10 \\
\hline 1926 & 45,00 & 19,80 & 6,06 \\
\hline 1927 & 51,77 & 22,35 & 6,75 \\
\hline 1928 & 53,22 & 23,00 & 7,10 \\
\hline 1929 & 56,53 & 25,60 & 7,80 \\
\hline 1930 & 58,42 & 25,60 & 8,00 \\
\hline 1931 & 61,82 & 27,95 & 8,25 \\
\hline 1932 & 54,68 & 24,10 & 6,95 \\
\hline 1933 & 44,23 & 20,20 & 6,85 \\
\hline 1934 & 43,03 & 19,18 & 6,45 \\
\hline 1935 & 42,37 & 19,38 & 6,63 \\
\hline 1936 & 41,99 & 19,57 & 6,68 \\
\hline 1937 & 41,68 & 19,54 & 6,64 \\
\hline 1938 & 41,28 & 19,48 & 6,54 \\
\hline
\end{tabular}

Źródło: [Sprawoz̨ania Spółki Brackiej..., 1922-1938].

W omawianym okresie systematycznie wzrastała liczba inwalidów oraz wdów korzystających ze świadczeń brackiej kasy pensyjnej. Natomiast odwrotna tendencja 
występowała w przypadku sierot. Ich liczba systematycznie malała, w efekcie zmian w zapisach statutowych. Dane o wysokości miesięcznych świadczeń pensyjnych dla wyżej wymienionych grup przedstawiono w tabeli 5 .

Wysokość wypłacanych świadczeń przez brackie kasy pensyjne zależała od kilku czynników, w tym: kategorii inwalidztwa, długości okresu składkowego oraz wysokości uiszczanych składek. W przypadku świadczeń sierocych ich wysokość uzależniona była od wysokości renty inwalidzkiej. Natomiast w latach kryzysu wysokość tego świadczenia powiązano z bieżącą koniunktura.

W Pszczyńskim Bractwie Górniczym wymiar świadczeń sierocych był korzystniejszy i wynosił odpowiednio: 22 zł dla pełnej sieroty i 11 zł dla półsieroty miesięcznie. Sieroty dysponowały także prawem do łączenia tego świadczenia ze świadczeniami z ubezpieczenia wypadkowego, co dodatkowo powiększało ich dochody [Wanatowicz, 1971].

Z punktu widzenia rencistów $\mathrm{i}$ ich dochodów istotne były koszty utrzymania, gdyż tylko poprzez określenie stosunku renty brackiej do kosztów utrzymania i do przeciętnej płacy górników można było określić realną wartość inwalidzkiego świadczenia rentowego. Z porównania kosztów utrzymania ze świadczeniami brackimi wynika, że w latach 20. koszty utrzymania rosły szybciej aniżeli świadczenia brackie (w latach 1924-1927 koszty utrzymania wzrosły o 73,69\% a renta inwalidzka tylko o 15\%). Relacja ta uległa pogorszeniu w pierwszej połowie lat 30. Tempo spadku przeciętnego świadczenia rentowego było porównywalne z tempem spadku ogólnych kosztów utrzymania. W latach 1930-1936 renty inwalidzkie spadły o 25,8\%, a ogólne koszty utrzymania o 24,3\%. Świadczenia wypłacane przez brackie kasy pensyjne kształtowały się na poziomie minimum kosztów utrzymania. Dochody pensjonistów nie przekraczały nawet 50\% miesięcznych dochodów zatrudnionych górników. Szczegółowe dane o dochodach czynnych oraz biernych członków kas pensyjnej prezentuje tabela 6 .

TABELA 6

Przeciętny miesięczny dochód górnika oraz przeciętna miesięczna pensja inwalidów w latach 1924-1938 (w zł)

\begin{tabular}{|l|c|c|c|c|c|}
\hline Rok & $\begin{array}{c}\text { Przeciętny } \\
\text { dochód } \\
\text { wórnictwie }\end{array}$ & $\begin{array}{c}\text { Przeciętna } \\
\text { pensja inwa- } \\
\text { lidzka }\end{array}$ & Rok & $\begin{array}{c}\text { Przeciętny } \\
\text { dochód } \\
\text { górnictwie }\end{array}$ & $\begin{array}{c}\text { Przeciętna } \\
\text { pensja inwa- } \\
\text { lidzka }\end{array}$ \\
\hline 1924 & 136,64 & 32,25 & 1932 & 168,04 & 54,68 \\
\hline 1925 & 107,52 & 44,16 & 1933 & 166,68 & 44,23 \\
\hline 1926 & 147,32 & 45,00 & 1934 & 163,72 & 43,03 \\
\hline 1927 & 173,68 & 51,77 & 1935 & 160,28 & 42,37 \\
\hline 1928 & 194,24 & 53,22 & 1936 & 162,24 & 41,99 \\
\hline 1929 & 221,08 & 56,53 & 1937 & 185,76 & 41,68 \\
\hline 1930 & 201,00 & 58,42 & 1938 & 216,48 & 41,28 \\
\hline 1931 & 179,04 & 61,82 & & & \\
\hline
\end{tabular}

Źródło: [Maly Rocznilk..., 1933-1939, tabela 62; Sprawozdania Spótki Brackiej...,1924-1938]. 
W latach 20. XX w., tj. na przestrzeni lat 1924-1929, systematycznie wzrastały dochody czynnych oraz biernych członków brackich kas pensyjnych. Sytuacja ulegała pogorszeniu w pierwszej połowie lat 30. Załamaniu koniunktury towarzyszył wzrost bezrobocia wśród górników oraz spadek ich dochodów miesięcznych, co niekorzystnie wpływało na finanse brackich kas pensyjnych. Spadek dochodów czynnych członków kas pensyjnych trwał do 1936 r., a pensjonistów aż do końca omawianego okresu.

Jak już wcześniej napisano, stan koniunktury decydował nie tylko o liczebności brackich kas pensyjnych, ale także o ich dochodach i kondycji finansowej - tabela 7 .

TABELA 7

Dochody i wydatki kasy pensyjnej Spółki Brackiej w Tarnowskich Górach w latach 1924-1938 (w zł)

\begin{tabular}{|l|c|c|c|}
\hline \multicolumn{1}{|c|}{ Rok } & Dochody & Wydatki & $\begin{array}{c}\text { Procent pokrycia } \\
\text { wydatków }\end{array}$ \\
\hline 1924 & 15328906 & 6725169 & 227,9 \\
\hline 1925 & 14720057 & 14722941 & 99,9 \\
\hline 1926 & 14177383 & 16796094 & 84,4 \\
\hline 1927 & 18234426 & 19624997 & 92,9 \\
\hline 1928 & 21175386 & 20671181 & 102,4 \\
\hline 1929 & 27070470 & 23343133 & 115,9 \\
\hline 1930 & 26211414 & 24960164 & 105,0 \\
\hline 1931 & 24992477 & 26442195 & 94,5 \\
\hline 1932 & 2240648 & 24434218 & 91,7 \\
\hline 1933 & 18901453 & 20657930 & 89,3 \\
\hline 1934 & 20704408 & 23180397 & 87,3, \\
\hline 1935 & 20957864 & 23991678 & 94,8 \\
\hline 1936 & 22685855 & 23908508 & 87,9 \\
\hline 1937 & 21602262 & 24550097 & 103,4 \\
\hline 1938 & 25967137 & 25107594 & \\
\hline
\end{tabular}

Źródło: [Sprawozdania Spótki Brackiej..., 1922-1938].

W latach 1924-1938 roczne budżety kasy pensyjnej Spółki Brackiej w Tarnowskich Górach aż dziesięciokrotnie wykazywały niedobór, a jedynie pięciokrotnie nadwyżkę. Największy niedobór odnotowano w 1935 r., przekroczył on wówczas kwotę 3 mln zł, tj. 12,6\% ogółu wydatków (trudna sytuacja finansowa kasy pensyjnej zmusiła skarb państwa do udzielenia jednorazowej subwencji na pokrycie bieżącego niedoboru). Niedobór próbowano pokryć przy pomocy środków własnych oraz kredytów bankowych, ale nie udało się [Woźniczka, 1956, s. 353-354]. Wzrost wydatków na świadczenia był efektem wzrostu liczby pensjonistów: inwalidów i wdów. Z danych zaprezentowanych w tabeli 7 wynika, że w omawianym okresie niekorzystnie zmienił się stosunek pensjonistów do członków czynnych, co pozostawało 
w ścisłym związku z poziomem zatrudnienia w przemyśle węglowym. Zwalniani starsi górnicy, po ukończeniu 60. roku życia i potwierdzeniu niezdolności do pracy zarobkowej, otrzymywali prawo do świadczeń emerytalno-rentowych.

Warto zaznaczyć, że świadczenia pensyjne, wypłacane przez brackie kasy pensyjne, były wyższe od podobnych świadczeń oferowanych przez powszechny system emerytalny. Pełne brackie świadczenie emerytalne w latach 1924-1938 wahało się w przedziale od 40 do $60 \mathrm{zł} \mathrm{miesięcznie.} \mathrm{W} \mathrm{tym} \mathrm{samym} \mathrm{czasie} \mathrm{robotnicy} \mathrm{objęci} \mathrm{po-}$ wszechnym ubezpieczeniem emerytalnym w województwie śląskim otrzymywali maksymalnie świadczenia w wysokości 40 zł miesięcznie [Wieniawa-Chmielewski, 1934, s. 532-536; Wanatowicz, 1995, s. 133].

Górnośląscy górnicy korzystali z przywileju łączenia świadczeń brackich ze świadczeniami powszechnego ubezpieczenia emerytalnego (korzyści te ujawniały się po 60. roku życia). Na przestrzeni lat 1929-1938 liczba inwalidów łączących świadczenia pochodzące z obu źródeł zwiększyła się z 60\% do 67\% [Spótka Bracka..., nr 184]. Dzięki temu przywilejowi sytuacja materialna brackich pensjonistów i ich rodzin była korzystniejsza, a to z kolei przekładało się na popularność ubezpieczeń brackich.

\section{Stosunek ubezpieczonych górników do świadczeń oferowanych przez kasy pensyjne}

Górnośląscy górnicy, doceniając korzyści płynące z posiadania dodatkowego ubezpieczenia, akceptowali konieczność uiszczania dodatkowej składki na rzecz brackiej kasy pensyjnej. Na stosunek górników do ubezpieczeń pensyjnych wpływał bieżący stan koniunktury, gdyż decydował on o kondycji finansowej przedsiębiorstw górniczych i ogólnie o sytuacji na rynku pracy. W okresie dobrej koniunktury górnicy i przedsiębiorcy bez zastrzeżeń uiszczali składki i akceptowali wysokość świadczeń oferowanych przez brackie kasy pensyjne. Natomiast w okresie pogorszenia koniunktury górnicy, a zwłaszcza przedsiębiorcy, krytycznie odnosili się do wysokości nakładanych składek oraz wypłacanych świadczeń.

Wielki kryzys gospodarczy lat 30. przyczynił się do pogorszenia kondycji finansowej bractw oraz do zaostrzenia sprzeczności między czynnymi i biernymi członkami. Czynni członkowie wymuszali na władzach brackich uruchamianie programów naprawczych, które jednocześnie zakładały obniżkę wypłacanych świadczeń (zwłaszcza inwalidzkich) oraz uiszczanych składek.

Postulaty czynnych członków prowadziły do konfliktu interesów. Przedstawiciele inwalidów, wdów oraz sierot odrzucali programy oszczędnościowe i domagali się przywrócenia korzystniejszych rozwiązań. Roszczeniowa postawa biernych członków rodziła sprzeciw nie tylko władz brackich, ale także czynnych członków oraz przedsiębiorców górniczych, którzy otwarcie opowiadali się za dostosowaniem wysokości oferowanych świadczeń do stanu koniunktury.

Konflikt interesów nie marginalizował pozytywnych efektów ich funkcjonowania. Na szczególne uwypuklenie zasługują trzy pozytywne efekty: 
- minimalizacja ryzyka wystapienia konfliktów społecznych w górnośląskim przemyśle węglowym, co powiązane było z ochroną istniejących stosunków narodowościowo-własnościowych,

- gwarancja otrzymania dochodów przez członków w chwili niezdolności do pracy zawodowej bez względu na wiek,

- gwarancja pomocy medycznej dla rodzin członków brackich kas pensyjnych.

Plusy górniczych ubezpieczeń brackich dominowały więc nad ich niedociagnięciami. Ponadto plusy ubezpieczenia brackiego decydowały o niechętnym stosunku górników do rządowych wizji scentralizowania systemu ubezpieczeń.

\section{Podsumowanie}

Funkcjonowanie brackich ubezpieczeń górniczych w okresie międzywojennym było ściśle powiązane $z$ tempem życia gospodarczego. Każdorazowa zmiana w koniunkturze odbijała się na sytuacji finansowej instytucji brackich, co z kolei rzutowało na świadczenia oferowane przez brackie kasy pensyjne i brackie kasy chorych. W latach dobrej koniunktury i poprawy sytuacji na rynku pracy rosły dochody tych instytucji, a ich władze chętnie podwyższały wypłacane świadczenia.

Brackie kasy pensyjne oferowały świadczenia dostosowane do warunków pracy oraz potrzeb górników. Górnicze ubezpieczenia pensyjne zapewniały dodatkowe świadczenia emerytalno-rentowe dla górników i ich rodzin. Dodatkowe dochody podwyższały jakość życia górnośląskiej ludności i decydowały o pozytywnym obrazie tego regionu.

Instytucje brackie odgrywały istotną rolę w życiu publicznym polskiego Górnego Śląska, bowiem chętnie wspierały działalność organizacji charytatywnych i oświatowych, w tym: bezpłatne leczenie bezrobotnych w ramach Biura Opieki Lekarskiej dla Bezrobotnych, współfinansowanie akcji letniego wypoczynku dzieci i młodzieży pochodzącej z tego regionu, pomoc medyczna dla chorych na gruźlicę.

\section{Literatura}

Biały F., 1967, Zwiazek Przemystowców Górniczo-Hutniçzych 1914-1932, Zakład Narodowy im Ossolińskich, Wrocław-Warszawa-Kraków.

Ciagwa J., 1979, Wplyw centralnych organów Drugiej Rzecrypospolitej na ustawodawstwo ślaskie w latach 1922-1939, Wydawnictwo Uniwersytetu Śląskiego w Katowicach, Katowice.

Ciagwa J., 2005, Regulacja prawna interpelacji poselskich w Sejmie Ślaskim w latach 19221929, „Miscellanea Iuridica”, t. 7, s. 45-48.

Danowska-Prokop B., 2012, Sytuacja gospodarcza i spoteczna na Górnym Ślasku w okeresie miedsywojennym $i$ jej wplyw na ubespieczenia brackie, Wydawnictwo Uniwersytetu Ekonomicznego w Katowicach, Katowice. 
Drozdowski M., 1938, Zagadnienia gospodarcze w Konwencji Genewskiej (1922-1937), „Śląskie Wiadomości Gospodarcze”, nr 9, s. 209-210.

Falęcki T., 1967, Niemieckie i polskie partie polityczne wobec wygaśnięcia konwencii genewskiej w 1937 roku, „Zaranie Ślaskie”, z. 4, s. 683-697.

Gruber H., 1928, Ubezpieczenia robotników na Górmym Ślasku, „Przegląd Gospodarczy”, nr 1, s. 21-24.

Jastrzębowski M., 1923, Zabezpieczenie na wypadek bezrobocia, „Przegląd Gospodarczy”, nr 14, s. 511-516.

Jońca K., 1966, Polityka socjalna Niemiec w pržemyśle cię̇kim Górnego Ślaska 1871-1914, Instytut Śląski, Katowice.

Kozłowski W., 1923, Ubezpieczenia w Polsce, „Przegląd Gospodarczy”, nr 2, s. 8.

Maty Rocznike Statystyczny, 1933-1939, Główny Urząd Statystyczny, Warszawa

Mamrotowa M., 1933, Robotnicze kasy emerytalne na Górnym Ślasku a kryzys w butnictwie, „Przegląd Ubezpieczeń Społecznych”, nr 12, s. 644-647

Marcoń W., 2009, Autonomia Ślaska 1922-1939, Wydawnictwo Adam Marszałek, Toruń.

Popiołek F., 1946, Opieka społeczna w prz̨emyśle butniczo-górniczymm na ziemiach polskich, Instytut Śląski, Cieszyn.

Spótka Bracka w Tarnowskich Górach, Archiwum Państwowe w Katowicach, Katowice, nr 184.

Sprawozdania Spótki Brackiej w Tarnowskich Górach, 1922-1938.

Szczęśniak M., 2003, Zarys dziejów ubezpieczeńn na ziemiach polskich, Wyższa Szkoła Ubezpieczeń i Bankowości, Warszawa.

Ustawa Konstytucyjna z dnia 15 lipca 1920 r. zawierająca statut organiczny Województwa Śląskiego, Dz.U. RP nr 73, poz. 497.

Wanatowicz M., 1971, Pszçyńskie Bractwo Górnicze w okresie międzywojennym, „Studia i materiały z dziejów Śląska”, t. 9.

Wanatowicz M., 1973, Ubezpieczenia brackie na Górnym Ślasku w latach 1922-1939, PWN, Warszawa-Kraków.

Wanatowicz M., 1995, Ubezpieczenia brackie na bistorycznym obszarze Górnego Ślaska, [w]: Górny Ślask - drieje medycyny i farmacji, problemy dokumentacji i metodologii badań, Dyba M. (red.), PMG Sp. z o.o. w Katowicach, Katowice.

Wieniawa-Chmielewski C., 1934, Górnicze ubezpieczenie pensyjne na Ślasku, „Przegląd Ubezpieczeń Społecznych", nr 9, s. 532-536.

Woźniczka F., 1956, Mineło sto lat od czasu założenia byłej Spótki Brackiej w Tarnowskich Górach, „Przegląd Ubezpieczeń Społecznych”, nr 12, s. 353-355. 